$\begin{array}{ll}\text { Nama } & : \text { Hasniar } \\ \text { Nim } & : 90100118042 \\ \text { Kelas } & : \text { Ekonomi Islam A }\end{array}$

\title{
KONSEP PEMIKIRAN MERKANTILISME
}

Konsep ekonomi Merkantilisme muncul sekitar abad ke-18 dengan membawa pandangan ekonomi terkait konsep kesejahteraan negara. Di dalam suatu negara kesejahteraan, negara mempunyai tugas di semua sektor kehidupan terutama di sektor perekonomian. Tugas negara dalam menciptakan kesejahteraan tidak terbatas pada suatu golongan tertentu dalam masyarakat, tetapi untuk semua warga negara dan tidak pula untuk suatu waktu dalam kehidupan individu, dimulai dari dilahirkan sampai meninggal. Negara harus memperhatikan kesejahteraan rakyatnya baik kesejahteraan individu maupun kesejahteraan masyarakat dan inilah yang disebut universalisme kesatuan. Seiring dengan lahirnya konsepsi negara kesejahteraan ini, timbul. Pula apa yang dinamakan "konsepsi ekonomi kesejahteraan" yang memberikan dasar dasar teoritis ekonomis kepada konsepsi negara kesejahteraan itu ${ }^{1}$

"merkantilisme" berasal dari kata merchant, yang berarti perdagang. Menurut paham ini, jika tiap negara ingin menjadi maju harus melakukan perdagangan dengan negara lain. Sumber kekayaan negara akan diperoleh melalui "surplus" perdagangan luar negeri yang diterima dalam bentuk emas atau perak, sehingga kebijakan pada saat waktu adalah mendorong ekspor dan membatasi impor. Adapun Negara-negara Eropa yang menganut paham merkantilisme waktu itu antara lain: Portugis, Spanyol, Inggris, Perancis dan Belanda Inti kebijakan merkantilisme adalah :

1. Emas dan perak merupakan bentuk kekayaan yang disukai. Oleh karenanya terdapat larangan mengekspor logam mulia.

2. Negara harus meningkatkan kekayaan dan merugikan negara lain

\footnotetext{
${ }^{1}$ Yulia Hafiah. “ Kebijakan Ekonomi Indonesia Ditinjau Dari Konsep Dasar Ekonomi Islam” Millah, Vol. IV, No. 2, Januari, 2005. Hal 33.
} 
3. Dalam kebijakan ekspor-impor, berkeyakinan bahwa perkembangan harus dapat diraih dan dikelola dengan cara meraih surplus yang sangat besar dari penerimaan ekspor yang melebihi belanja untuk impor barang.

4. Kolonisasi dan monopolisasi perdagangan harus harus dilaksanaka secara ketat agar kaum koloni tunduk dan tergantung pada negara induk.

5. Penentangan atas bea, pajak, dan restrinsik intern terhadap mobilitas barang.

6. Harus membangun pemerintah pusat yang kuat, guna menjamin kebjaksanaan merkantilisme tersebut.

7. Pertumbuhan penduduk sangat penting dan SDM yang tinggi untuk memenuhi pemasukan kepentingan militer serta pengelolaan merkantilisme yang kuat. ${ }^{2}$

\section{Tokoh-tokoh merkantilisme:}

1. Jean Bodin (1530-1596) seorang ilmuwan berbangsa prancis yang dapat dikatakan sebagai orang pertama yang secara sistematis menyajikan teori tentang uang dan harga.

2. Thomas Mun (1571-1641) seorang saudagar kaya raya yang berasal dari Inggris. Banyak menulis masalah perdagangan luar negeri

3. Jean Baptis Colbert (1691-1683) tujuan kebijakan yang dibuat lebih diarahkan pada kekuasaan dan kejayaan negara dari pada untuk menungkatkan kekayaan orang perorang.

4. Sir Williarn Petty (1623-1687) menganggap penting arti bekerja (labor) jauh lebih penting dari sumber daya tanah.

5. David Hume (1711-1776) sahabat Adam Smith, sering berdiskusi mengenai perdagangan-perdaganganya terhadap ekonomi, bukunya adalah of Balance of Trade, yang membicarakan tentang harga-harga yang sebagian dipengaruhi oleh jumlah uang. ${ }^{3}$

2 Ubad Al Faruq, Edi Mulyanto, Sejarah Teori-Teori Ekonomi, (Unpam Press: Tanggerang Selatan) Mei 2017, Hlm 37

${ }^{3}$ F.R. Albanjari. ). Pemikiran Ilmu Ekonomi ( Analisis Komparatif Ekonomi Masa Pra Klasik Dan Masa Rasulullah Saw). Eksyar . Volume 04, Nomor 01, Juni 2017. Hal 25-26. 


\section{DAFTAR PUSTAKA}

Albanjari, F. R. (2017). Pemikiran Ilmu Ekonomi (Analisis Komparatif Ekonomi Masa Pra Klasik Dan Masa Rasulullah Saw): Fatkhur Rohman Albanjari. EKSYAR: Jurnal Ekonomi Syari'ah \& Bisnis Islam, 4 (1) , 20-37.

Ubad Al Faruq, Edi Mulyanto, Sejarah Teori-Teori Ekonomi, (Unpam Press: Tanggerang Selatan) Mei 2017

Hafizah, Y. (2016). kebijakan ekonomi indonesia ditinjau dari konsep dasar ekonomi islam. Millah: Jurnal Studi Agama, 4 (2), 31-46. 